Chirurgia (2017) 112: 308-319

No. 3, May - June

Copyright@ Celsius

http://dx.doi.org/10.21614/chirurgia.112.3.308

\title{
Curative-intent Surgery for Perihilar Cholangiocarcinoma with and without Portal Vein Resection - A Comparative Analysis of Early and Late Outcomes
}

\author{
Traian Dumitrașcu' ${ }^{1}$, Cezar Stroescu', Vladislav Brașoveanu', Vlad Herlea², Mihnea Ionescu', Irinel Popescu ${ }^{1}$ \\ "Dan Setlacec" Center of General Surgery and Liver Transplantation, Fundeni Clinical Institute, Bucharest, Romania \\ 2Department of Pathology, Fundeni Clinical Institute, Bucharest, Romania
}

Corresponding author:

Traian Dumitrașcu, MD

"Dan Setlacec" Center of General Surgery

and Liver Transplant

Fundeni Clinical Institute

Fundeni Street no 258, 022328

Bucharest, Romania

E-mail: traian.dumitrascu@srchirurgie.ro

\begin{abstract}
Rezumat
Chirurgia cu viză curativă a colangiocarcinoamelor perihilare cu și fără rezecție de venă portă - studiu comparativ al rezultatelor postoperatorii imediate și la distanță
\end{abstract}

Introducere: Siguranța rezecției de venă portă în chirurgia colangiocarcinoamelor perihilare a fost deja dovedită în Asia, America şi Europa de Vest. Totuşi, nu există nici un fel de date referitoare la acest subiect, care să provină din Europa de Est. Scopul studiului este de a evalua comparativ rezultatele postoperatorii imediate şi pe termen lung după rezecția cholangiocarcinoamelor perihilare, cu şi fără rezecție de venă portă.

Pacienți şi metode: Datele a 21 de pacienți rezecați pentru colangiocarcinoame perihilare ce au asociat rezecția venei porte au fost comparate cu datele a 102 pacienți fără rezecție de venă portă. Pentru analiza comparativă a datelor din cele două grupuri s-au folosit teste statistice specifice.

Rezultate: Rezecția venei porte a fost realizată la $17 \%$ dintre pacienți. In grupul pacienților cu rezecție asociată de venă portă au fost realizate semnificativ mai multe trisecționectomii drepte $(\mathrm{p}=$ $0.031)$ şi rezectii de lob caudat $(p=0.049)$. Ca urmare, atât timpul operator $(p=0.015)$ cât şi pierderea de sânge intraoperator $(p=$ 0.002) au fost semnificativ mai mari în acest grup de pacienți cu rezecție de venă portă. Nu s-au constatat diferențe semnificative între cele două grupuri de pacienți în ceea ce priveşte rata complicațiilor severe postoperatorii, mortalitatea postoperatorie şi chimioterapia adjuvantă. Totuşi, în grupul pacienților cu rezecție de venă portă, rata insuficenței hepatice postoperatorii cu impact clinic 
a fost semnificativ mai mare $(p=0.001) . \mathrm{Nu}^{-}$-au constatat diferențe semnificative între grupuri în ceeea ce priveşte timpul de supraviețuire (34 vs. 26 luni, p = 0.566). Prezența invaziei venoase documentată histologic s`a dovedit a avea un impact negativ semnificativ asupra supraviețuirii la distanță, în grupul pacienților cu rezecție de venă portă ( $\mathrm{p}=0.027)$.

Concluzii: Rezecția venei porte asociată chirurgiei cu viză curativă pentru colangiocarcinoamele perihilare poate fi realizată în condiții de siguranță, fără a creşte în mod semnificativ rata de complicații şi mortalitatea postoperatorie. Totuşi, riscul de a dezvolta insuficiență hepatică postoperatorie cu impact clinic este semnificativ mai mare când se asociază rezecția venei porte. În plus, trebuie să ne aşteptăm la o creştere importantă a timpului operator şi a cantității de sânge pierdute intraoperator atunci când se asociază rezecția venei porte. Prezența invaziei venoase documentată histologic are un impact negativ semnificativ asupra supraviețuirii la distanță.

Cuvinte cheie: colangiocarcinom perihilar; rezecție de venă portă; complicații postoperatorii; supraviețuire

\begin{abstract}
Introduction: The safety of portal vein resection (PVR) during surgery for perihilar cholangiocarcinoma (PHC) has been demonstrated in Asia, America, and Western Europe. However, no data about this topic are reported from Eastern Europe. The aim of the present study is to comparatively assess the early and long-term outcomes after resection for PHC with and without PVR.

Patients and methods: The data of 21 patients with PVR were compared with those of 102 patients with a curative-intent surgery for PHC without PVR. The appropriate statistical tests were used to compare different variables between the groups.

Results: A PVR was performed in $17 \%$ of the patients. In the PVR group, significantly more right trisectionectomies $(\mathrm{p}=0.031)$ and caudate lobectomies (0.049) were performed and, as expected, both the operative time $(\mathrm{p}=0.015)$ and blood loss $(\mathrm{p}=0.002)$ were significantly higher. No differences between the groups were observed regarding the severe postoperative morbidity and mortality rates, and completion of adjuvant therapy. However, in the PVR group the postoperative clinicallyrelevant liver failure rate was significantly higher $(\mathrm{p}=0.001)$. No differences between the groups were observed for the median overall survival times (34 vs. 26 months, $p=0.566$ ). A histological proof of the venous tumor invasion was observed in $52 \%$ of the patients with a PVR and was associated with significantly worse survival $(\mathrm{p}=0.027)$.

Conclusion: A PVR can be safely performed during resection for PHC, without significant added severe morbidity or mortality rates. However, clinically-relevant liver failure rates are significantly higher when a PVR is performed. Furthermore, increased operative times and blood loss should be expected when a PVR is performed. Histological tumor invasion of the portal vein is associated with significantly worse survival.
\end{abstract}

Key words: perihilar cholangiocarinoma, portal vein resection, complications, survival

\section{Introduction}

Perihilar cholangiocarcinomas (PHC) are considered as relatively rare tumors. The concept of PHC has evolved over the years. Thus, initially, all the cholangiocarcinomas that involved or required the bile duct bifurcation resection were considered as $\mathrm{PHC}$, according to the Johns Hopkins definition proposed in 1996 (1). More recently, in 2014, the group from the Nagoya University re-considered the PHC as the cholangiocarcinomas involving de hilar bile 
duct, between the right side of the umbilical part of the left portal vein and the left side of the origin of the right posterior portal vein (2). Thus, the patients with large mass-forming intrahepatic cholangiocarcinomas (outside the proposed boundaries) were excluded from the PHC group. It appears that long-term survivals after resection of these large mass-forming intrahepatic cholangicarcinomas are worse than survivals after resection of PHC, as defined by the Nagoya University group $(3,4)$.

A negative resection margins surgery represents the most important determinant of survival in patients with $\mathrm{PHC}(5-8)$. The curative-intent surgery for PHC has significantly changed over the years from simple bile duct resection $(1,9,10)$ to more complex surgical procedures $(5,8,11)$. Thus, nowadays, a curative-intent surgery for PHC includes bile duct resection, loco-regional lymph nodes dissection, caudate lobectomy and, usually, a major hepatectomy $(3,5,8,11,12)$. These complex surgical procedures were associated with significantly improved long-term survival rates compared with simple bile duct resection (13), however, at the expense of increased morbidity rates and relatively high mortality rates (8). Thus, the 5-year survival rates of up to $40.4 \%$ were reported in large recent series of patients resected for $\mathrm{PHC}$, with up to $73 \%$ morbidity and up to $14.3 \%$ 90-day mortality rates (8). Postoperative liver failure and bile leak are the most frequent complications after major hepatectomies for PHC $(7,14)$.

A multidisciplinary approach in experienced surgical centers is mandatory to mitigate both morbidity and mortality rates and to obtain improved survivals in patients with PHC (3,5,8, 11,14,15). A PHC should be preoperatively differentiated from a benign Klatskin-mimicking lesion to avoid unnecessary extensive resections, albeit the differentiation between the two entities remains challenging (16).

The PHC have a particular pattern of spread towards loco-regional invasion (17). Thus, due to local anatomical consideration, the portal vein invasion in $\mathrm{PHC}$ is not uncommon. Furthermore, a portal vein invasion is no longer a contraindication for resection in patients with PHC when a safe venous reconstruction is feasible $(7,8,11)$. Although challenging, the safety of a portal vein resection (PVR) during curative-intent surgery for PHC has been demonstrated in several studies $(6,7,11,18-20)$. However, the impact of a PVR in PHC surgery remains controversial and previous comparative studies reached conflicting results $(5,7,11$, 17-29), none including patients from Eastern Europe. Furthermore, meta-analyses comparing the outcomes of patients with and without a PVR for PHC did not reach the same conclusions (29-33).

The practice of curative-intent surgery and the safety of a PVR in PHC in East European countries is poorly known because very few studies were published $(3,8,14,34-37)$. The experience gained in our surgical center with curative-intent surgery for $\mathrm{PHC}$ has been reflected in previous publications $(3,8,14,38)$.

The aim of the present study is to comparatively assess the early and long-term outcomes after resection for PHC with and without PVR, in a relatively large single-center experience.

\section{Patients and Methods}

\section{Patient Cohort}

Between 1996, January $1^{\text {st }}$ and 2014, December $31^{\text {st }}$, at our Department of Surgery, 127 patients underwent a curative-intent surgery for PHC. From the analysis were excluded four patients (3 patients with associated hepatic artery resection and reconstruction and one patient with associated pancreatico-duodenectomy). Hepatic artery resection and pancreatico-duodenectomy might have a detrimental effect on both early and long-term outcomes $(2,6,29,30)$. Thus, the remaining 123 patients were divided into two groups: with PVR (PVR group - 21 patients) and without PVR (no PVR group - 102 patients).

Demographics, clinical, pathological, early and long-term outcomes data were compared between the two groups from a prospective electronic database established at our Department.

A PHC was defined according to the Nagoya University definition (2). A PVR was electively 


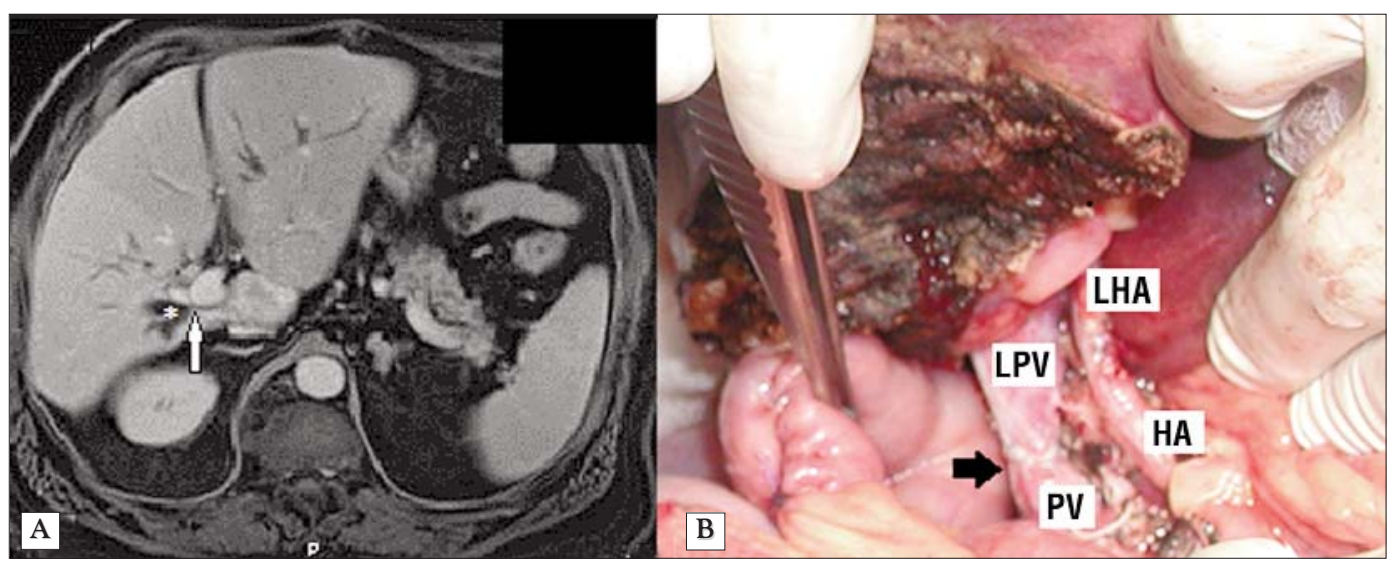

Figure 1. (A) Magnetic resonance imaging in a patient with a type III A Bismuth PHC invading the emergence of the right portal vein requiring a PVR (the asterisk marks the tumor and the arrow marks the tumor invasion of the emergence of the right portal vein); (B) Intraoperative aspects after bile duct resection, loco-regional lymph nodes dissection, caudate lobectomy and right hemi-hepatectomy with PVR for a type III A Bismuth PHC invading the portal vein (the arrow marks the end-to-end portal anastomosis; PV - portal vein; LPV - left portal vein; HA - proper hepatic artery; LHA - left hepatic artery)

performed when the portal vein invasion was detected or suspected at the preoperative imaging (Fig. 1 A) or intraoperative exploration, and a safe venous reconstruction was considered as possible (Fig. $1 \mathrm{~B}$ and 2). Our institution criteria of resectability for PHC and surgical procedures were described elsewhere (3) and are in agreement with the international guidelines (12).

\section{Assessment of Early and Long-term Outcomes}

Morbidity was defined as in-hospital complications and was assessed according to the DindoClavien classification (39). For the patients with more than one complication, the highest grade of complication was assigned. The posthepatectomy liver failure (40), hemorrhage (41) and bile leak (42) were defined and graded according to the International Study Group of Liver Surgery (ISGLS). The postoperative mortality was considered at 90-days.

\section{Statistical Analysis}

Data are expressed as the number (percentage) for categorical variables and median (range) for continuous variables. Fisher's exact test (two-tailed) was used to compare the categorical variables while Mann-Whitney test (two-tailed)

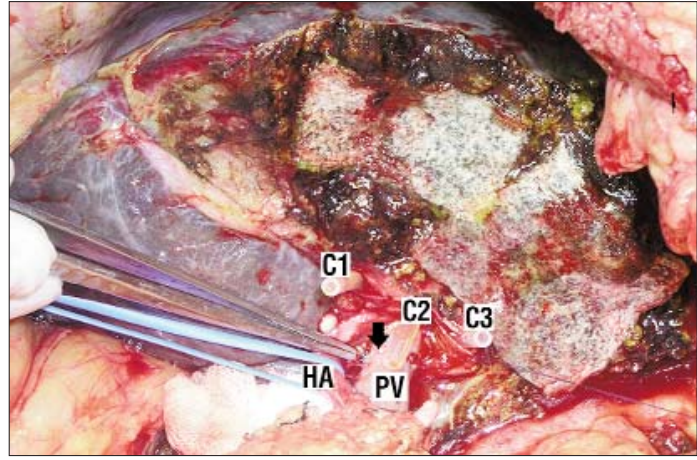

Figure 2. Intraoperative aspects after bile duct resection, loco-regional lymph nodes dissection, caudate lobectomy and left hemi-hepatectomy with PVR for a type III B Bismuth PHC invading the portal vein (the arrow marks the end-to-end portal anastomosis; PV - portal vein; HA - proper hepatic artery; C1, C2, C3 - bile ducts with stents inside)

was used for continuous variables. Median follow-up time was estimated using the reversed Kaplan-Meier curves and median overall survival time was estimated using the KaplanMeier curves; the comparisons were made using the log-rank test. Overall survival time was considered the time from resection to death occurrence or last follow-up (June $1^{\text {st }}, 2015$ ). $P$ values less than 0.05 were considered statistically significant. Statistical analyses 
were performed with the SPSS (Statistical Packages for Social Sciences) version 20.0 software (SPSS Inc., Chicago, IL).

\section{Results}

\section{Demographics, Clinical and Operative characteristics}

The rate of PVR was $17 \%$ in the present cohort of patients, and a segmental venous resection was performed in all these cases. A primarily end-to-end anastomosis was possible in 20 patients (95\%), while one patient (5\%) needed a synthetic graft interposition.

No differences between the groups were observed regarding age, associated co-morbidities, cirrhosis or cholangitis, preoperative bilirubin serum level, preoperative biliary drainage rate, preoperative albumin, hemoglobin, neutrophil-tolymphocyte ratio and CA 19-9 serum level, as shown in Table 1.

Significantly more males were found in the PVR group compared with the group of patients without PVR ( $81 \%$ vs. $52 \%, p=0.016)$. Furthermore, more right trisectionectomies and caudate lobectomies were performed in the PVR group, as shown in Table 1. As expected, both the operative time and estimated blood loss were significantly higher in the group of patients with PVR, as shown in Table 1.

\section{Pathology Data}

No differences between the groups were observed regarding the histological tumor type, tumor diameter, TNM stages, perineural invasion and negative resection margins rates, as shown in Table 2 . The histological proof of tumor invasion into the resected portal vein (V1) was confirmed in 11 patients (52\%) from the PVR group.

\section{Postoperative Data}

There were no significant differences between the groups regarding the severe morbidity, 90-day mortality, and clinically-relevant posthepatectomy bile leak and hemorrhage rates, as shown in Table 3.

The clinically-relevant post-hepatectomy liver failure rate was significantly higher in

Table 1. Curative-intent surgery for PHC in patients without PVR (no PVR group - 102 patients) vs. patients with PVR (PVR group - 21 patients): comparative analysis of demographics, clinical and operative parameters

\begin{tabular}{|c|c|c|c|}
\hline Parameter & $\begin{array}{l}\text { no PVR group } \\
\text { (102 patients) }\end{array}$ & $\begin{array}{l}\text { PVR group } \\
\text { (21 patients) }\end{array}$ & $P$ value \\
\hline Age, years & $59(21-77)$ & $56(40-71)$ & $0.143^{1}$ \\
\hline Gender, male & $53(52 \%)$ & $17(81 \%)$ & $0.016^{2}$ \\
\hline Co-morbidities & $32(31 \%)$ & $2(9.5 \%)$ & $0.058^{2}$ \\
\hline Cirrhosis & $5(5 \%)$ & $1(5 \%)$ & $1^{2}$ \\
\hline Preoperative bilirubin serum level, $\mathrm{mg} / \mathrm{dl}$ & $8(0.2-35)$ & $8.8(0.7-23)$ & $0.888^{1}$ \\
\hline Cholangitis & $20(20 \%)$ & $7(33 \%)$ & $0.244^{2}$ \\
\hline Preoperative biliary drainage & $24(24 \%)$ & $6(29 \%)$ & $0.589^{2}$ \\
\hline Preoperative albumin serum level, $\mathrm{g} / \mathrm{dl}$ & $4(2-5.4)$ & $3.6(2-4.6)$ & $0.102^{1}$ \\
\hline Preoperative hemoglobin serum level, g/ dl & $12.5(7.5-16)$ & $12.3(7.8-15.3)$ & $0.840^{1}$ \\
\hline Preoperative neutrophil-to-lymphocyte ratio & $3.2(1-16.2)$ & $3.3(1.2-23.2)$ & $0.612^{1}$ \\
\hline Preoperative CA 19-9 serum level, U/ ml & $174(1-1400)$ & $400(40-5000)$ & $0.101^{1}$ \\
\hline Right hemi-hepatectomies & $24(24 \%)$ & $8(38 \%)$ & $0.179^{2}$ \\
\hline Right trisectionectomies & $7(7 \%)$ & $5(24 \%)$ & $0.031^{2}$ \\
\hline Caudate lobectomies & $58(57 \%)$ & $17(81 \%)$ & $0.049^{2}$ \\
\hline Operative time, min & $240(120-620)$ & $300(180-650)$ & $0.015^{1}$ \\
\hline Estimated blood loss, ml & $400(100-15000)$ & $800(300-12000)$ & $0.002^{1}$ \\
\hline
\end{tabular}

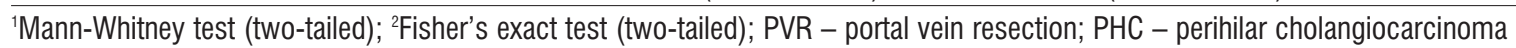


Table 2. Curative-intent surgery for PHC in patients without PVR (no PVR group - 102 patients) vs. patients with PVR (PVR group - 21 patients): comparative analysis of pathology data

\begin{tabular}{lccc}
\hline Parameter & $\begin{array}{c}\text { no PVR group } \\
\text { (102 patients) }\end{array}$ & $\begin{array}{c}\text { PVR group } \\
\text { (21 patients) }\end{array}$ & P value \\
\hline Infiltrative type tumor & $52(51 \%)$ & $14(67 \%)$ & $0.233^{1}$ \\
\hline Tumor diameter, cm & $2.5(0.4-10)$ & $3(0.5-10)$ & $0.131^{2}$ \\
\hline AJCC T3/ T4 stages & $51(50 \%)$ & $14(67 \%)$ & $0.230^{1}$ \\
\hline Positive loco-regional lymph nodes & $36(35 \%)$ & $12(57 \%)$ & $0.085^{1}$ \\
\hline Perineural invasion & $35(34 \%)$ & $15(71 \%)$ & $0.800^{1}$ \\
\hline AJCC stages 3-4 & $64(63 \%)$ & $15(71 \%)$ & $0.68^{1}$ \\
\hline Negative resection margins (R0) & $80(78 \%)$ & $0.568^{1}$ \\
\hline
\end{tabular}

${ }^{1}$ Fisher's exact test (two-tailed); ${ }^{2}$ Mann-Whitney test (two-tailed); AJCC - the American Joint Commission on Cancer; PVR - portal vein resection; PHC - perihilar cholangiocarcinoma

the PVR group, as shown in Table 3.

A portal vein thrombosis was observed in the early setting in 3 patients $(2.4 \%)$ of the present cohort (Fig. 3), without significant differences between the groups, as shown in Table 3.

No differences between the groups were observed for the postoperative hospital stays, as shown in Table 3.

\section{Long-term Survival Comparative Analysis}

Two patients $(9.5 \%)$ in the PVR group and 6 patients $(5.9 \%)$ in the group without a PVR were excluded from the survival analyses due to 90-day postoperative death or lost from the follow-up $(p=0.623)$.

The median follow-up time was 110 months
(4-174 months) in the group of patients without a PVR and 56 months (4 - 80 months) in the PVR group, without any significant difference $(p=0.064)$. No differences between the groups were observed regarding the completion of adjuvant treatment rates, as shown in Table 3.

The median overall survival time was 26 months $(4-174$ months $)$ in the group of patients without a PVR and 34 months $(4-80$ months) in the PVR group, without any significant difference $(\mathrm{p}=0.566)$ (Fig. 4 A). However, in the group of PVR patients, the overall survival time was significantly worse in the group of patients with a histological proof of tumor venous invasion, compared with the patients without tumor venous invasion: 12 months $(4-51$ months $)$ vs. 43 months $(4-80$

Table 3. Curative-intent surgery for PHC in patients without PVR (no PVR group - 102 patients) vs. patients with PVR (PVR group - 21 patients): comparative analysis of early and long-term postoperative outcomes

\begin{tabular}{lccc}
\hline Parameter & $\begin{array}{c}\text { no PVR group } \\
\text { (102 patients) }\end{array}$ & $\begin{array}{c}\text { PVR group } \\
\text { (21 patients) }\end{array}$ & P value \\
\hline Severe postoperative complications (grade III-IV Dindo) & $19(19 \%)$ & $5(24 \%)$ & $0.557^{1}$ \\
\hline 90-day mortality & $5(5 \%)$ & $2(10 \%)$ & $0.341^{1}$ \\
\hline Grade B/C liver failure & $12(12 \%)$ & $9(43 \%)$ & $0.001^{1}$ \\
\hline Grade B/C bile leak & $27(26 \%)$ & $4(19 \%)$ & $0.588^{1}$ \\
\hline Grade B/C hemorrhage & $5(5 \%)$ & $2(10 \%)$ & $0.341^{1}$ \\
\hline Portal vein thrombosis & $1(1 \%)$ & $15(4-40)$ & $0.072^{1}$ \\
\hline Postoperative hospital stay, days & $15(1-65)$ & $11(52 \%)$ & $0.845^{2}$ \\
\hline Completion of adjuvant therapy & $48(47 \%)$ & $0.811^{1}$ \\
\hline
\end{tabular}

${ }^{1}$ Fisher's exact test (two-tailed); ${ }^{2}$ Mann-Whitney test (two-tailed); PVR - portal vein resection; PHC - perihilar cholangiocarcinoma 


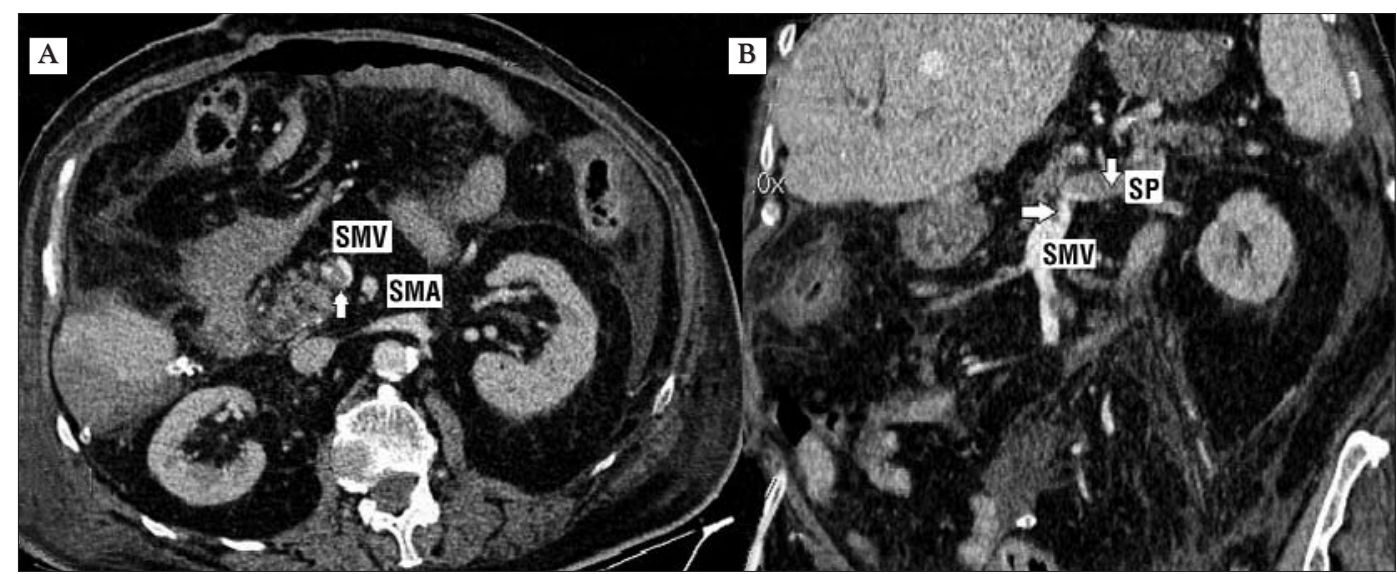

Figure 3. (A) Axial plane contrast enhanced computer tomography showing a postoperative portal vein thrombosis extended to the superior mesenteric vein after bile duct resection, loco-regional lymph nodes dissection, caudate lobectomy and right hemi-hepatectomy with PVR for a type III A Bismuth PHC invading the portal vein; (B) Coronal plane contrast enhanced computer tomography showing a postoperative portal vein thrombosis extended to the superior mesenteric and splenic veins after bile duct resection, loco-regional lymph nodes dissection, caudate lobectomy and right hemihepatectomy with PVR for a type III A Bismuth PHC invading the portal vein (the arrows mark the thrombus; SMV - superior mesenteric vein; SV - splenic vein; SMA - superior mesenteric artery)

months) $(\mathrm{p}=0.027)($ Fig. 4 B).

The 1-, 2-, 3- and 5-year survival rates were $69 \%, 51 \%, 43 \%$ and $26 \%$ in the PVR group and $76 \%, 52 \%, 42 \%$ and $28 \%$ in the group of patients without a PVR, respectively.
Furthermore, in the subgroup of patients with a PVR, the 1-, 2-, 3- and 5-year survival rates were $80 \%, 80 \%, 64 \%$ and $48 \%$ in the V0 group and $50 \%, 22 \%, 22 \%$ and $0 \%$ in the $\mathrm{V} 1$ group of patients, respectively.
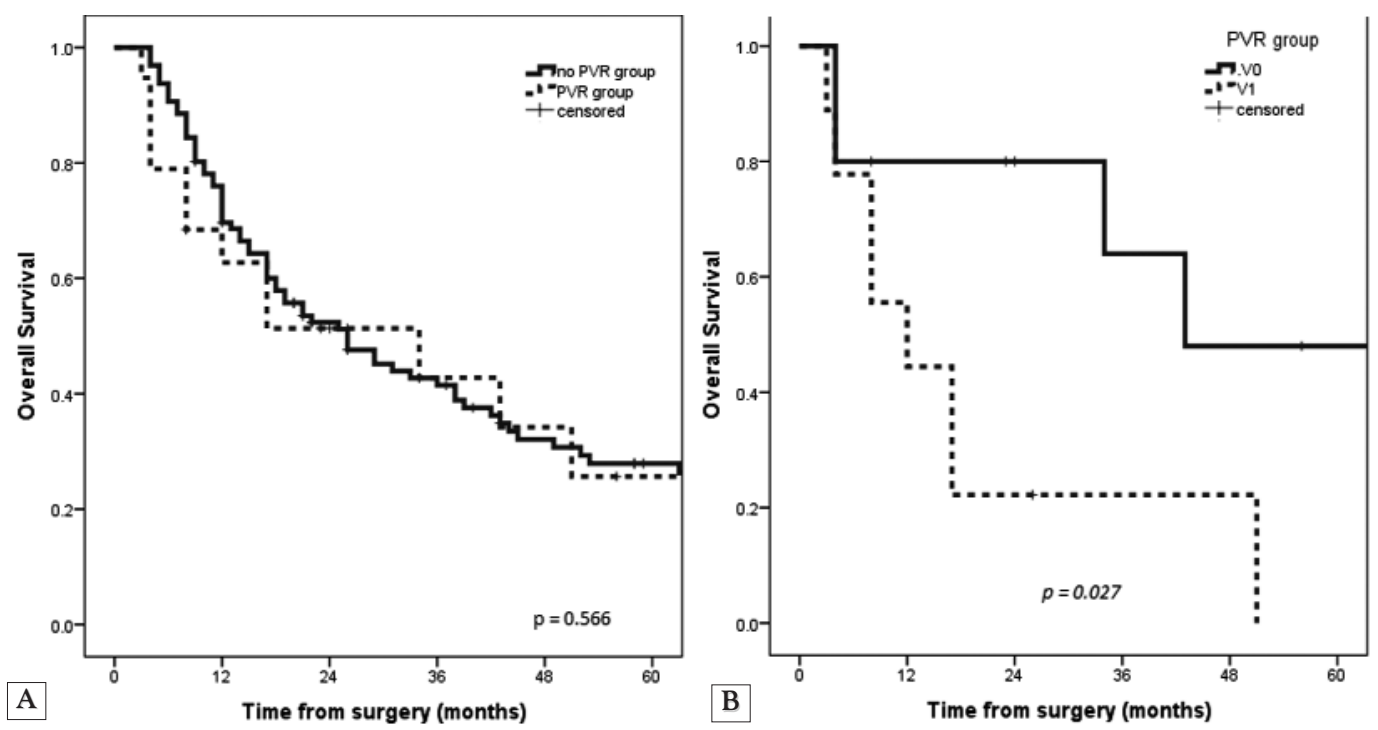

Figure 4. Kaplan-Meier comparative curves for overall survival in patients (A) with curative-intent surgery for PHC with and without a PVR (B) with and without a histological venous invasion 


\section{Discussion}

To the best of our knowledge, this is the largest series of patients with a curative-intent surgery for PHC published to date in Eastern Europe and the first study assessing the impact of a PVR in this part of the world. The clinical, operative, pathological and postoperative early and late outcomes data in the present cohort of patients are similar to those reported in other previous large series from high-volume centers worldwide, as a recent review has shown (8).
The reported incidence of a PVR during curative-intent surgery for PHC in large recent series varies from $8 \%$ to $44 \%$ (8). The PVR is more frequently encountered in surgical centers from Japan $(2,6,11,22,25)$ while in the remaining part of the world the PVR during curative-intent surgery for PHC is reported in $9.6 \%$ to $22 \%$ of the patients $(5,8,15,18,27-29$, 43). In the present cohort of patients, a PVR was performed in $17 \%$ of the cases.

In most of the previously reported patients, a segmental PVR was necessary, and a primarily

Table 4. Curative-intent surgery for PHC with and without PVR: relevant comparative studies from the literature

\begin{tabular}{|c|c|c|c|c|c|c|c|c|c|}
\hline Author, year & Period & $\begin{array}{l}\text { Total } \\
\text { patients/ } \\
\text { PVR }\end{array}$ & $\begin{array}{l}\text { PVR } \\
\text { rate } \\
(\%)\end{array}$ & $\begin{array}{c}\text { Mortality } \\
(\%) \\
\text { (PVR vs. } \\
\text { no PVR) }\end{array}$ & $\begin{array}{c}\text { Morbidity } \\
(\%) \\
\text { (PVR vs. } \\
\text { no PVR) }\end{array}$ & $\begin{array}{c}\text { R0 rate } \\
\text { (\%) } \\
\text { (PVR vs. } \\
\text { no PVR) }\end{array}$ & $\begin{array}{l}\text { V1 } \\
\text { rate } \\
(\%)\end{array}$ & $\begin{array}{l}\text { Median OS } \\
\text { time } \\
\text { (PVR vs. } \\
\text { no PVR) }\end{array}$ & $\begin{array}{c}\text { 5-years } \\
\text { survival } \\
\text { rate } \\
\text { (PVR vs. } \\
\text { no PVR) }\end{array}$ \\
\hline $\begin{array}{l}\text { Klempnauer (24), } 1997 \\
\text { Hanover Medical School, } \\
\text { Germany }\end{array}$ & 1971-1995 & $151 / 39$ & $25.8 \%$ & $\begin{array}{c}17.1 \% \text { vs. } \\
7.8 \%^{\mathrm{a}}\end{array}$ & NA & $\begin{array}{l}73.2 \% \text { vs. } \\
75.8 \%\end{array}$ & $33.3 \%$ & NA & $\begin{array}{c}34 \% \text { vs. } \\
34 \%\end{array}$ \\
\hline $\begin{array}{l}\text { Munoz (26), 2002, } \\
\text { Mount Sinai School } \\
\text { of Medicine, USA }\end{array}$ & $1990-2001$ & $28 / 10$ & $35.7 \%$ & $\begin{array}{c}10 \% \text { vs. } \\
0 \%{ }^{\mathrm{a}}\end{array}$ & NA & NA & $50 \%$ & NA & $\begin{array}{c}22 \% \text { vs. } \\
38 \%\end{array}$ \\
\hline $\begin{array}{l}\text { Ebata (19), 2003, } \\
\text { Nagoya University, Japan }\end{array}$ & $1979-2000$ & $160 / 52$ & $32.5 \%$ & $\begin{array}{l}9.6 \% \text { vs. } \\
9.3 \%{ }^{\mathrm{a}}\end{array}$ & $\begin{array}{c}84.6 \% \text { vs. } \\
78.7 \%\end{array}$ & $\begin{array}{c}69.2 \% \text { vs. } \\
88 \%^{\dagger}\end{array}$ & $69.2 \%$ & NA & $\begin{array}{c}9.9 \% \text { vs. } \\
36.8 \%^{\dagger}\end{array}$ \\
\hline $\begin{array}{l}\text { Miyazaki (17), 2007, } \\
\text { Chiba University, Japan }\end{array}$ & $1981-2004$ & $161 / 34$ & $20.4 \%$ & $\begin{array}{c}8.8 \% \text { vS. } \\
4.2 \%\end{array}$ & $\begin{array}{c}38 \% \text { vs. } \\
36 \%\end{array}$ & $\begin{array}{c}56 \% \text { vs. } \\
65 \%\end{array}$ & $80 \%$ & NA & $\begin{array}{c}14 \% \text { vs. } \\
30 \%^{\dagger}\end{array}$ \\
\hline $\begin{array}{l}\text { Hirano (22), 2009, } \\
\text { Hokkaido University, Japan }\end{array}$ & $1999-2007$ & $64 / 43$ & $67 \%$ & $\begin{array}{c}5.6 \% \text { vs. } \\
4.8 \%{ }^{\mathrm{a}}\end{array}$ & $\begin{array}{c}33.3 \% \text { vs. } \\
57.1 \%^{\dagger}\end{array}$ & $\begin{array}{c}95.3 \% \text { vs. } \\
95.2 \%\end{array}$ & $44.2 \%$ & NA & NA \\
\hline $\begin{array}{l}\text { Song (27), } 2009 \text {, } \\
\text { Asan Medical Center, Korea }\end{array}$ & $1989-2005$ & $259 / 51$ & $19.7 \%$ & $\begin{array}{l}9.8 \% \text { VS. } \\
2.9 \%\end{array}$ & $\begin{array}{c}47.1 \% \text { vs. } \\
39.4 \%\end{array}$ & NA & $54.9 \%$ & $\begin{array}{c}18.1 \text { vs. } 27.2 \\
\text { months }^{\dagger}\end{array}$ & $\begin{array}{c}18.5 \% \text { vs. } \\
26.7 \%^{\dagger}\end{array}$ \\
\hline $\begin{array}{l}\text { Hemming (21), 2011, } \\
\text { University of California } \\
\text { San Diego, USA }\end{array}$ & $1999-2010$ & $95 / 42$ & $44.2 \%$ & $\begin{array}{l}8 \% \text { vs. } \\
2 \%^{a}\end{array}$ & NA & NA & $41 \%$ & NA & $\begin{array}{c}40 \% \text { vs. } \\
40 \%\end{array}$ \\
\hline $\begin{array}{l}\text { Neuhaus (20), 2012, } \\
\text { Charite Campus Virchow } \\
\text { Berlin, Germany }\end{array}$ & $1990-2004$ & $100 / 50$ & $50 \%$ & $\begin{array}{l}12.4 \% \text { vs. } \\
11.2 \%^{\mathrm{b}}\end{array}$ & NA & NA & NA & NA & $\begin{array}{c}58 \% \text { vs. } \\
29 \%^{\dagger}\end{array}$ \\
\hline $\begin{array}{l}\text { de Jong (18), 2012, } \\
\text { multi-institutional, } \\
\text { Western Europe and USA }\end{array}$ & $1984-2010$ & $305 / 51$ & $16.7 \%$ & $\begin{array}{c}17.6 \% \text { vs. } \\
10.6 \%^{\mathrm{b}}\end{array}$ & NA & $\begin{array}{c}66.7 \% \text { vs. } \\
66.4 \%\end{array}$ & $49 \%$ & NA & NA \\
\hline $\begin{array}{l}\text { Yu (29), 2014, } \\
\text { Second Military Medical } \\
\text { University, China }\end{array}$ & 1998-2010 & $238 / 25$ & $10.5 \%$ & NA & $\begin{array}{c}32 \% \text { vs. } \\
16.9 \%\end{array}$ & NA & NA & NA & $\begin{array}{l}0 \% \text { vs. } \\
21.8 \%^{\dagger}\end{array}$ \\
\hline $\begin{array}{l}\text { Wang (28), 2015, } \\
\text { First Affiliated Hospital, } \\
\text { Sun Yat-Sen University, China }\end{array}$ & $2005-2012$ & $154 / 34$ & $22 \%$ & $\begin{array}{l}0 \% \text { vs. } \\
0.9 \%{ }^{a}\end{array}$ & $\begin{array}{c}37.5 \% \text { vs. } \\
35.1 \%\end{array}$ & NA & NA & $\begin{array}{l}20 \text { vs. } 32 \\
\text { months }\end{array}$ & $\begin{array}{c}25 \% \text { vs. } \\
35.7 \%\end{array}$ \\
\hline $\begin{array}{l}\text { Hoffmann (23), 2015, } \\
\text { Heidelberg, Germany }\end{array}$ & $2001-2012$ & $60 / 21$ & $35 \%$ & $\begin{array}{c}19.1 \% \text { vs. } \\
12.8 \%\end{array}$ & $\begin{array}{c}100 \% \text { vs. } \\
28.2 \%\end{array}$ & $\begin{array}{c}57.1 \% \text { vs. } \\
59 \%\end{array}$ & $42.8 \%$ & $\begin{array}{c}32.3 \text { vs. } 28.1 \\
\text { months }\end{array}$ & $\begin{array}{c}20 \% \text { vs. } \\
17.8 \%\end{array}$ \\
\hline $\begin{array}{l}\text { Matsuyama (25), 2016, } \\
\text { Yokohama, Japan }\end{array}$ & $1992-2014$ & $172 / 54$ & $31.3 \%$ & $\begin{array}{c}3.7 \% \text { vS. } \\
4 \%\end{array}$ & $\begin{array}{c}70.3 \% \text { vs. } \\
82.4 \%\end{array}$ & $\begin{array}{c}79.6 \% \text { vs. } \\
74.3 \%\end{array}$ & $40.7 \%$ & NA & $\begin{array}{c}51 \% \text { vs. } \\
46 \%\end{array}$ \\
\hline Present series & $1996-2014$ & $123 / 21$ & $17 \%$ & $\begin{array}{c}10 \% \text { vs. } \\
5 \%{ }^{\mathrm{b}}\end{array}$ & $\begin{array}{c}24 \% \text { vs. } \\
19 \%^{*}\end{array}$ & $\begin{array}{c}71 \% \text { vs. } \\
78 \%\end{array}$ & $52 \%$ & $\begin{array}{c}34 \text { vs. } 26 \\
\text { months }\end{array}$ & $\begin{array}{c}26 \% \text { vs. } \\
28 \%\end{array}$ \\
\hline
\end{tabular}

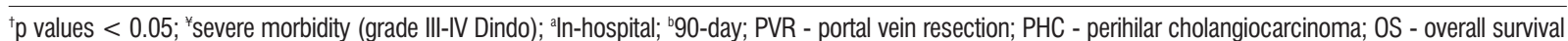
time; NA - not available 
end-to-end anastomosis was possible $(5,6,11,19$, $21,22,27,28,43)$, as it was the case in the present series.

It is worth to mention that nowadays there are two attitudes regarding the issue of PVR during surgery for PHC. Thus, few surgical centers propose the routine en-bloc PVR ("notouch" technique)(7,20,22,44-46), while most of the surgical teams recommend the selective use of the PVR $(2,5,6,11,15,18,21,23,25,28$, 29,43 ), only when the preoperative imaging or intraoperative exploration suspect portal vein invasion by the tumor (8), as in was the case in the present series. A recent systematic review and meta-analysis have shown that the sensitivity and specificity of a preoperative contrastenhanced computed tomography in detecting a portal vein invasion in a PHC patient are $89 \%$ and $92 \%$, respectively (47).

The impact of a PVR on postoperative outcomes after curative-intent surgery for PHC has been explored in several previous studies and remains controversial (Table 4). However, technically, a portal vein encasement appears to complicate the surgical strategy in a patient with PHC (48).

Regarding the early outcomes, some studies associated a PVR with trends towards increased mortality rates $(15,24,27,49)$ while others did not $(6,11,18-23,25,28)$, as it was the case in the present series. No differences in morbidity rates were observed in most of the published studies (17-22,25,27-29,46), as it was the case in the present series. Only one study showed significantly increased morbidity rates when a PVR is performed (23). Recent meta-analyses of comparative studies of combined PVR for PHC have shown no significantly increased morbidity rates for the PVR group (29-33). Significantly increased mortality rates were reported for the PVR group in four meta-analyses (29-31,33), while one meta-analysis did not identify any differences (32).

Klempnauer and co-workers reported in 1997 a portal vein thrombosis rate with subsequent liver failure in $7.7 \%$ of the patients with PVR for PHC (24). The reported portal vein thrombosis rates after curative-intent surgery for PHC with PVR in the previous series vary between $0 \%$ and $10 \%(17,22,23,25$, $26,30,45)$ and appears to be significantly higher compared with the patients without a PVR(30). In the present series of patients with a PVR, the portal vein thrombosis rate was $9.5 \%$, not significantly different from the group of patients without a PVR.

The reported liver failure rates after PVR in previous studies vary between $1.9 \%$ and $57 \%$, not significantly different compared with the patients without a PVR (23,30-32). In the present series the postoperative liver failure rate in the PVR group was high (43\%). Interestingly, Neuhaus and co-workers showed significantly increased liver failure rates when a PVR is performed (20), as it was the case in the present series. The large variability of reported liver failure rates might be significantly influenced by the variations in the definition of liver failure. Thus, the postoperative liver failure rates after hepatectomies appear to be higher when the ISGLS definition is used $(14,23)$, as it was the case in the present series. Nagino and $\mathrm{co}^{-}$ workers, in a single-center experience of 574 patients with curative-intent surgery for PHC with and without a PVR, reported a postoperative liver failure rate of $53.5 \%$ using the ISGLS definition (11). Nevertheless, male gender and right trisectionectomies were significantly associated with an increased risk of postoperative liver failure in patients with combined PVR hepatectomies in a study (50). In the present series, male gender and right trisectionectomies rates were significantly higher in the PVR group (Table 1).

Previous studies did not identify any significant differences of operative time and blood loss between the patients with and without a PVR for PHC $(17,22,23,26,46)$. However, Wang and co-workers identify significantly increased blood loss when a PVR is performed (28). In the present series, both the operative time and blood loss were significantly higher when a PVR was performed.

In the present study no differences of survivals were found between the groups of patients with and without a PVR for PHC. This might be explained by the fact that no differences between the groups were observed 
for any relevant prognostic factor that could influence the long-term survival. Thus, our previous studies have shown that negative resection margins, completion of adjuvant therapy and neutrophil-to-lymphocyte ratio are independent prognostic factors for the long-term outcome in patients resected for PHC (3). In the present series no differences between the groups were observed for the negative resection margins, completion of adjuvant therapy rates and neutrophil-to-lymphocyte ratio (Table 1 and 2). Furthermore, no differences between the groups were observed for the perineural invasion and metastatic lymph nodes rates (Table 2). Significantly increased perineural invasion and metastatic lymph nodes rates were found for the PVR group in three metaanalyses, compared with the patients without a PVR (31-33).

Four meta-analyses have shown conflicting results regarding the impact of a PVR on the negative resection margin rates (30-33). Thus, Chen and co-workers (32) and Bai and coworkers (31) identify significantly lower negative resection margin rates in the PVR group, while $\mathrm{Wu}$ and co-workers and Abbas and $\mathrm{co}^{-}$ workers showed no significant differences $(30,33)$.

Some studies identified a PVR as negative prognostic factor for long-term survival $(6,11$, $19,27)$, while others did not $(5,15,18,21-26,28,43$, 51-53) (Table 4). It is worth to mention that there are several studies that associated a PVR with significantly improved survivals in PHC $(7,20)$. Five recent meta-analyses of comparative studies have shown conflicting results about the impact of a combined PVR for PHC on the longterm survival rates $\left(29,31^{-33}\right)$. Thus, Wu and coworkers (33) showed no statistically significant differences for the 5-year survival rates, while Abbas and co-workers (30), Yu and co-workers (29), Chen and co-workers (32) and Bai and coworkers (31) reported significantly worse survivals when a PVR was performed.

Histological proof of venous invasion by the tumor was demonstrated in $52 \%$ of the patients and was associated with significant worse survivals in the present series. Our previous studies showed similar findings for portal vein invasion in pancreatic head adenocarcinoma (54). A recent multi-institutional study performed in Japan that included 394 patients with PVR for PHC has shown that portal vein invasion is an independent predictor for worse survivals (2). Other studies did not identify the portal vein invasion as a significant prognostic factor $(18,19,45,51)$. The reported incidence of V1 rates in the previous studies varies between $22 \%$ and $80 \%(5,7,11,17-29,45)$ (Table 4). A recent study has shown that histopathological tumor invasion of the portal vein is associated with an aggressive tumor biology (55).

The present study has some limitations: the retrospective design, relatively small number of patients in the PVR group with consequently limited statistical power and the heterogeneity of the adjuvant therapy. Furthermore, not all the patients were routinely investigated in the early postoperative setting for asymptomatic portal vein thrombosis.

\section{Conclusions}

The rate of PVR during curative-intent surgery for PHC in the present series (17\%) is similar to those previously reported in other high-volume centers of Western countries. A PVR can be safely performed during resection for $\mathrm{PHC}$, without significant added severe morbidity or mortality rates. However, clinically-relevant liver failure rates are significantly higher when a PVR is performed. Furthermore, increased operative times and blood loss should be expected when a PVR is performed. Histological tumor invasion of the portal vein is associated with significantly worse survivals.

\section{Funding and conflict of interests: none}

\section{Acknowledgments}

The paper has been exposed as an oral presentation at the HBP Surgery Week 2017 and the $46^{\text {th }}$ Annual Congress of the Korean Association of Hepato-Biliary-Pancreatic Surgery (March $31^{\text {st }}$ - April $1^{\text {st }}, 2017$, Jeju, Korea). T. Dumitrascu received a Travel Grant from the Korean Association of Hepato-Biliary-Pancreatic Surgery. 


\section{References}

1. Nakeeb A, Pitt HA, Sohn TA, Coleman J, Abrams RA, Piantadosi S, et al. Cholangiocarcinoma. A spectrum of intrahepatic, perihilar, and distal tumors. Ann Surg 1996;224(4):463-73.

2. Ebata T, Kosuge T, Hirano S, Unno M, Yamamoto M, Miyazaki M, et al. Proposal to modify the International Union Against Cancer staging system for perihilar cholangiocarcinomas. Br J Surg 2014; 101(2):79-88.

3. Dumitrascu T, Chirita D, Ionescu M, Popescu I. Resection for hilar cholangiocarcinoma: analysis of prognostic factors and the impact of systemic inflammation on long-term outcome. J Gastrointest Surg 2013;17(5):913-24.

4. Ionel ZE, Dumitrascu T, Brasoveanu V, Lupescu I, Anghel R, Herlea $\mathrm{V}$, et al. Intrahepatic cholangiocarcinoma-the impact of pathological characteristics on the long-term outcome after resection. Modern Medicine 2014;21(4):241-51.

5. Lee SG, Song GW, Hwang S, Ha TY, Moon DB, Jung DH, et al. Surgical treatment of hilar cholangiocarcinoma in the new era: the Asan experience. J Hepatobiliary Pancreat Sci 2010;17(4):476-89.

6. Miyazaki M, Kimura F, Shimizu H, Yoshidome H, Ohtsuka M, Kato A, et al. Recent advance in the treatment of hilar cholangiocarcinoma: hepatectomy with vascular resection. J Hepatobiliary Pancreat Surg 2007;14(5):463-8.

7. Neuhaus P, Jonas S, Bechstein WO, Lohmann R, Radke C, Kling N, et al. Extended resections for hilar cholangiocarcinoma. Ann Surg 1999;230(6):808-18.

8. Popescu I, Dumitrascu T. Curative-intent surgery for hilar cholangiocarcinoma: prognostic factors for clinical decision making. Langenbecks Arch Surg 2014;399(6):693-705.

9. Bismuth $\mathrm{H}$, Nakache R, Diamond $\mathrm{T}$. Management strategies in resection for hilar cholangiocarcinoma. Ann Surg 1992;215(1):318.

10. Launois B, Campion JP, Brissot P, Gosselin M. Carcinoma of the hepatic hilus. Surgical management and the case for resection. Ann Surg 1979;190(2):151-7.

11. Nagino M, Ebata T, Yokoyama Y, Igami T, Sugawara G, Takahashi $Y$, et al. Evolution of surgical treatment for perihilar cholangiocarcinoma: a single-center 34-year review of 574 consecutive resections. Ann Surg 2013;258(1):129-40.

12. Mansour JC, Aloia TA, Crane CH, Heimbach JK, Nagino M, Vauthey JN. Hilar cholangiocarcinoma: expert consensus statement. HPB (Oxford) 2015;17(8):691-9.

13. Capussotti L, Vigano L, Ferrero A, Muratore A. Local surgical resection of hilar cholangiocarcinoma: is there still a place? HPB (Oxford) 2008;10(3):174-8.

14. Dumitrascu T, Brasoveanu V, Stroescu C, Ionescu M, Popescu I. Major hepatectomies for perihilar cholangiocarcinoma: Predictors for clinically relevant postoperative complications using the International Study Group of Liver Surgery definitions. Asian J Surg 2016;39(2):81-9.

15. Nuzzo G, Giuliante F, Ardito F, Giovannini I, Aldrighetti L, Belli G, et al. Improvement in perioperative and long-term outcome after surgical treatment of hilar cholangiocarcinoma: results of an Italian multicenter analysis of 440 patients. Arch Surg 2012;147(1):26-34.

16. Dumitrascu T, Ionescu M, Ciurea S, Herlea V, Lupescu I, Popescu I. Klatskin-mimicking lesions-a case series and literature review. Hepatogastroenterology 2010;57(101):961-7.

17. Miyazaki M, Kato A, Ito H, Kimura F, Shimizu H, Ohtsuka M, et al. Combined vascular resection in operative resection for hilar cholangiocarcinoma: does it work or not? Surgery 2007;141(5): 581-8.

18. de Jong MC, Marques H, Clary BM, Bauer TW, Marsh JW, Ribero $D$, et al. The impact of portal vein resection on outcomes for hilar cholangiocarcinoma: a multi-institutional analysis of 305 cases. Cancer 2012;118(19):4737-47.

19. Ebata T, Nagino M, Kamiya J, Uesaka K, Nagasaka T, Nimura Y.
Hepatectomy with portal vein resection for hilar cholangiocarcinoma: audit of 52 consecutive cases. Ann Surg 2003:238(5):720-7.

20. Neuhaus P, Thelen A, Jonas S, Puhl G, Denecke T, Veltzke-Schlieker $W$, et al. Oncological superiority of hilar en bloc resection for the treatment of hilar cholangiocarcinoma. Ann Surg Oncol 2012; 19(5):1602-8.

21. Hemming AW, Mekeel K, Khanna A, Baquerizo A, Kim RD. Portal vein resection in management of hilar cholangiocarcinoma. $\mathrm{J} \mathrm{Am}$ Coll Surg 2011;212(4):604-13.

22. Hirano S, Kondo S, Tanaka E, Shichinohe T, Tsuchikawa T, Kato K, et al. Outcome of surgical treatment of hilar cholangiocarcinoma: a special reference to postoperative morbidity and mortality. J Hepatobiliary Pancreat Sci 2010;17(4):455-62.

23. Hoffmann K, Luible S, Goeppert B, Weiss KH, Hinz U, Buchler MW, et al. Impact of portal vein resection on oncologic long-term outcome in patients with hilar cholangiocarcinoma. Surgery 2015; 158(5):1252-60.

24. Klempnauer J, Ridder GJ, von WR, Werner M, Weimann A, Pichlmayr R. Resectional surgery of hilar cholangiocarcinoma: a multivariate analysis of prognostic factors. J Clin Oncol 1997; 15(3):947-54.

25. Matsuyama R, Mori R, Ota Y, Homma Y, Kumamoto T, Takeda K, et al. Significance of vascular Rrsection and reconstruction in surgery for hilar cholangiocarcinoma: with special reference to hepatic arterial resection and reconstruction. Ann Surg Oncol 2016;23 (Suppl 4):475-84.

26. Munoz L, Roayaie S, Maman D, Fishbein T, Sheiner P, Emre S, et al. Hilar cholangiocarcinoma involving the portal vein bifurcation: long-term results after resection. J Hepatobiliary Pancreat Surg 2002;9(2):237-41.

27. Song GW, Lee SG, Hwang S, Kim KH, Cho YP, Ahn CS, et al. Does portal vein resection with hepatectomy improve survival in locally advanced hilar cholangiocarcinoma? Hepatogastroenterology 2009;56(93):935-42.

28. Wang ST, Shen SL, Peng BG, Hua YP, Chen B, Kuang M, et al. Combined vascular resection and analysis of prognostic factors for hilar cholangiocarcinoma. Hepatobiliary Pancreat Dis Int 2015;14(6):626-32.

29. Yu W, Gu Z, Shi S, Shen N, Zhang Y. Effect evaluation of vascular resection for patients with hilar cholangiocarcinoma: original data and meta-analysis. Cell Biochem Biophys 2014;69(3):509-16.

30. Abbas S, Sandroussi C. Systematic review and meta-analysis of the role of vascular resection in the treatment of hilar cholangiocarcinoma. HPB (0xford) 2013;15(7):492-503.

31. Bai T, Chen J, Xie ZB, Ma L, Liu JJ, Zhu SL, et al. Combined portal vein resection for hilar cholangiocarcinoma. Int J Clin Exp Med 2015;8(11):21044-52.

32. Chen $\mathrm{W}, \mathrm{Ke} \mathrm{K}, \mathrm{Chen} \mathrm{YL}$. Combined portal vein resection in the treatment of hilar cholangiocarcinoma: a systematic review and meta-analysis. Eur J Surg Oncol 2014;40(5):489-95.

33. Wu XS, Dong P, Gu J, Li ML, Wu WG, Lu JH, et al. Combined portal vein resection for hilar cholangiocarcinoma: a meta-analysis of comparative studies. J Gastrointest Surg 2013;17(6):1107-15.

34. Neagos HC, Graur F, Neagos OE, Dumitrascu DI, Mihaileanu F, Vlad $L$. The multimodal treatment of central and peripheral cholangiocarcinoma - analysis based on a single center experience. Clujul Med 2015;88(2):203-7.

35. Patiutko I, Poliakov AN, Kotelnikov AG, Sagaidak IV, Gakhramanov AD, Moroz EA, et al. Surgical and combined treatment of patients with Klatzkin's tumor. Khirurgiia (Mosk) 2014;(10):33-2.

36. Vladov N, Lukanova T, Takorov I, Mutafchiyski V, Vasilevski I, Sergeev S, et al. Single centre experience with surgical treatment of hilar cholangiocarcinoma. Chirurgia (Bucur ) 2013;108(3):299303.

37. Zharikov YO, Kovalenko YA, Olifir AA, Kalinin DV, Czhao AV. [Clinico-pathological factors and prognosis scale for portal cholangiocarcinoma]. Khirurgiia (Mosk) 2017:(1):27-31. (in Russian)

38. Chirita D, Calita M, Grasu M, Dumitru R, Gramaticu I, Croitoru A, et 
al. Metachronous Ampulla of Vater Carcinoma after Curative-Intent Surgery for Klatskin Tumor. Chirurgia (Bucur) 2015;110(4):379-83.

39. Dindo D, Demartines N, Clavien PA. Classification of surgical complications: a new proposal with evaluation in a cohort of 6336 patients and results of a survey. Ann Surg 2004;240(2):205-13

40. Rahbari NN, Garden OJ, Padbury R, Brooke-Smith M, Crawford M, Adam R, et al. Posthepatectomy liver failure: a definition and grading by the International Study Group of Liver Surgery (ISGLS). Surgery 2011;149(5):713-24.

41. Rahbari NN, Garden OJ, Padbury R, Maddern G, Koch M, Hugh TJ, et al. Post-hepatectomy haemorrhage: a definition and grading by the International Study Group of Liver Surgery (ISGLS). HPB (Oxford) 2011;13(8):528-35.

42. Koch M, Garden OJ, Padbury R, Rahbari NN, Adam R, Capussotti $\mathrm{L}$, et al. Bile leakage after hepatobiliary and pancreatic surgery: a definition and grading of severity by the International Study Group of Liver Surgery. Surgery 2011;149(5):680-8.

43. Song SC, Choi DW, Kow AW, Choi SH, Heo JS, Kim WS, et al. Surgical outcomes of 230 resected hilar cholangiocarcinoma in a single centre. ANZ J Surg 2013;83(4):268-74.

44. Jonas S, Benckert C, Thelen A, Lopez-Hanninen E, Rosch T, Neuhaus P. Radical surgery for hilar cholangiocarcinoma. Eur $\mathrm{J}$ Surg Oncol 2008;34(3):263-71.

45. Molina V, Sampson J, Ferrer J, Diaz A, Ayuso JR, Sanchez-Cabus $S$, et al. Surgical treatment of perihilar cholangiocarcinoma: early results of en bloc portal vein resection. Langenbecks Arch Surg 2017;402(1):95-104.

46. Tamoto E, Hirano S, Tsuchikawa T, Tanaka E, Miyamoto M, Matsumoto J, et al. Portal vein resection using the no-touch technique with a hepatectomy for hilar cholangiocarcinoma. HPB (Oxford) 2014;16(1):56-61.

47. Ruys AT, van Beem BE, Engelbrecht MR, Bipat S, Stoker J, Van
Gulik TM. Radiological staging in patients with hilar cholangiocarcinoma: a systematic review and meta-analysis. $\mathrm{Br} \mathrm{J}$ Radiol 2012; 85(1017):1255-62.

48. Hines KF, Pawlik TM. Portal vein encasement complicates resection of Klatskin's tumor. JAAPA 2010;23(1):30-2.

49. Gerhards MF, Van Gulik TM, de Wit LT, Obertop H, Gouma DJ. Evaluation of morbidity and mortality after resection for hilar cholangiocarcinoma-a single center experience. Surgery 2000; 127(4):395-404.

50. Bachellier P, Rosso E, Pessaux P, Oussoultzoglou E, Nobili C, Panaro $F$, et al. Risk factors for liver failure and mortality after hepatectomy associated with portal vein resection. Ann Surg 2011; 253(1):173-9.

51. Chen XP, Lau WY, Huang ZY, Zhang ZW, Chen YF, Zhang WG, et al. Extent of liver resection for hilar cholangiocarcinoma. $\mathrm{Br} \mathrm{J}$ Surg 2009;96(10):1167-75.

52. Cho MS, Kim SH, Park SW, Lim JH, Choi GH, Park JS, et al. Surgical outcomes and predicting factors of curative resection in patients with hilar cholangiocarcinoma: 10-year single-institution experience. J Gastrointest Surg 2012;16(9):1672-9.

53. Matsuo K, Rocha FG, Ito K, D'Angelica MI, Allen PJ, Fong Y, et al. The Blumgart preoperative staging system for hilar cholangiocarcinoma: analysis of resectability and outcomes in 380 patients. J Am Coll Surg 2012;215(3):343-55.

54. Dumitrascu T, Dima S, Brasoveanu V, Stroescu C, Herlea V, Moldovan S, et al. Impact of a portal/superior mesenteric vein resection during pancreatico-duodenectomy for pancreatic head adenocarcinoma. Minerva Chir 2014;69(6):301-13.

55. Lapshyn H, Bolm L, Kohler I, Werner M, Billmann FG, Bausch D, et al. Histopathological tumor invasion of the mesenterico-portal vein is characterized by aggressive biology and stromal fibroblast activation. HPB (Oxford) 2017;19(1):67-74. 